\title{
Pharmacokinetics and skin-tissue penetration of daptomycin in rats
}

This article was published in the following Dove Press journal:

Clinical Pharmacology:Advances and Applications

21 May 2015

Number of times this article has been viewed

\section{Kazuaki Matsumoto' \\ Masashi Kitaoka' \\ Yuko Kuroda' \\ Kazuro Ikawa ${ }^{2}$ \\ Norifumi Morikawa ${ }^{2}$ \\ Junichi Sasaki ${ }^{3}$ \\ Osamu Iketani ${ }^{4}$ \\ Satoshi Iwata ${ }^{4}$ \\ Tetsuya Horino ${ }^{5}$ \\ Seiji Hori ${ }^{5}$ \\ Junko Kizu'}

'Division of Practical Pharmacy, Keio University Faculty of Pharmacy, Tokyo, ${ }^{2}$ Department of Clinical Pharmacotherapy, Hiroshima University, Hiroshima, ${ }^{3}$ Department of Emergency and Critical Care Medicine, ${ }^{4}$ Center for Infectious Diseases and Infection Control, Keio University School of Medicine, ${ }^{5}$ Department of Infectious Diseases and Infection Control, Jikei University School of Medicine, Tokyo, Japan
Correspondence: Kazuaki Matsumoto Division of Practical Pharmacy, Keio University Faculty of Pharmacy, I-5-30 Shibakoen, Minato-ku,

Tokyo I05-85 I2, Japan

Tel/fax +8I 354002656

Email matsumoto-kz@pha.keio.ac.jp
Background: Daptomycin is recommended for complicated skin and skin-structure infections. However, information on the penetration of daptomycin into skin is limited. Therefore, the aim of this in vivo investigation was to determine the pharmacokinetics and skin penetration of daptomycin in rats.

Materials and methods: Concentrations of daptomycin were determined by high-performance liquid chromatography. A noncompartmental pharmacokinetic analysis was conducted to estimate the rate and extent of daptomycin penetration from the systemic circulation into skin tissue. Since protein binding of daptomycin in rat serum was $89.3 \%$, the free maximum concentration $\left(\mathrm{C}_{\max }\right)$ and free area under the curve from time 0 to infinity $\left(\mathrm{AUC}_{0-\infty}\right)$ for plasma were calculated as follows: $f \mathrm{C}_{\text {max, plasma }}=(1-0.893) \times \mathrm{C}_{\text {max, plasma }}, f \mathrm{AUC}_{0-\infty \text {, plasma }}=(1-0.893) \times \mathrm{AUC}_{0-\infty \text {, plasma }}$. Results: The following values (mean \pm standard deviation) were obtained: $0.06 \pm 0 \mathrm{~L} / \mathrm{h} / \mathrm{kg}$ for total clearance $\left(\mathrm{CL}_{\text {total }}\right), 0.44 \pm 0.06$ hours for elimination-rate constant, $1.58 \pm 0.23$ hours for half-life, $0.14 \pm 0.02 \mathrm{~L} / \mathrm{kg}$ for steady-state volume distribution, and $2.28 \pm 0.33$ hours for mean residence time. Time to $\mathrm{C}_{\max }$ was 3.0 hours for plasma and skin tissue. $\mathrm{C}_{\max }$ and $\mathrm{AUC}_{0-\infty}$ for plasma were $175.8 \pm 5.1 \mu \mathrm{g} / \mathrm{mL}$ and $811.8 \pm 31.9 \mu \mathrm{g} \times \mathrm{h} / \mathrm{mL}$, respectively. $\mathrm{C}_{\max }$ and $\mathrm{AUC}_{0-\infty}$ for skin tissue were $19.1 \pm 1.7 \mu \mathrm{g} / \mathrm{mL}$ and $113.9 \pm 21.8 \mu \mathrm{g} \times \mathrm{h} / \mathrm{mL}$, respectively. Furthermore, $f \mathrm{C}_{\max }$ and $f \mathrm{AUC}_{0-\infty}$ for plasma were $18.8 \mu \mathrm{g} / \mathrm{mL}$ and $86.9 \mu \mathrm{g} \times \mathrm{h} / \mathrm{mL}$, respectively. The degrees of skintissue penetration, defined as the $\mathrm{C}_{\text {max, skin tissue }} / f \mathrm{C}_{\text {max, plasma }}$ ratio and $\mathrm{AUC}_{0-\infty \text {, skin tissue }} / \mathrm{AUC}_{0-\infty \text {, plasma }}$ ratio, were 1.0 and 1.3 , respectively.

Conclusion: Daptomycin exhibited good penetration into skin tissue, supporting its use for the treatment of complicated skin and skin-structure infections. However, further studies are needed in infected patients in order to investigate the relationship between the antimicrobial efficacy of daptomycin and its drug concentrations in skin tissues.

Keywords: daptomycin, pharmacokinetics, rat, skin-tissue penetration

\section{Introduction}

Daptomycin is a cyclic lipopeptide antimicrobial agent that exhibits rapid and concentration-dependent bactericidal activity against aerobic and facultative Grampositive microorganisms. ${ }^{1}$ Its spectrum of activity includes susceptible and resistant Gram-positive cocci, including methicillin-resistant Staphylococcus aureus and multidrug-resistant Streptococcus pneumonia. Arbeit et al reported that daptomycin was effective as a standard therapy for the treatment of complicated skin and skin structure infections caused by Gram-positive pathogens. ${ }^{2}$ Daptomycin is recommended for complicated skin and skin-structure infections in clinical practice guidelines by the Infectious Disease Society of America for the treatment of methicillin-resistant S. aureus infections. ${ }^{3}$ However, information on the penetration of daptomycin into 
skin is limited. The penetration of daptomycin is still a matter of debate, particularly in light of its high plasma protein binding of $92 \%$ in humans and its relatively high molecular weight of 1,620 Da. ${ }^{4}$ These characteristics limit drug penetration from plasma to tissue. Therefore, the aim of this in vivo investigation was to determine the pharmacokinetics and skin penetration of daptomycin in rats.

\section{Materials and methods}

\section{Animal experimentation}

This study was reviewed and approved by the Animal Experimentation Committee of Keio University (12056-[0]), and was performed in compliance with its Animal Experimental Guidelines. Ten-week-old male Wistar rats were purchased from Sankyo Labo Service (Tokyo, Japan). Hair from the top of the head was removed using an electric clipper and depilatory cream 4 days prior to the administration of daptomycin. Rats were anesthetized with sevoflurane inhalation. Single-dose plasma pharmacokinetic studies were performed after the subcutaneous administration of $10 \mathrm{mg} / \mathrm{mL}$ daptomycin dissolved in saline. Blood samples and skin-tissue samples $(10 \times 15 \mathrm{~mm})$, which were removed from the top of the head, were obtained 1, 3, 5, 8, and 12 hours after the subcutaneous administration of daptomycin $(50 \mathrm{mg} / \mathrm{kg})$ (three animals per time point). After the skin-tissue sample was weighed, the sample was added to nine times its volume weight of $1 \%$ phosphate buffer ( $\mathrm{pH} 6.0$ ). ${ }^{5}$ The mixture was homogenized using a Polytron homogenizer to prepare a skin-tissue suspension. The suspension was stored at $4{ }^{\circ} \mathrm{C}$ for 18 hours to extract daptomycin and then centrifuged (3,000 rpm, 15 minutes). ${ }^{5}$ The supernatant was available for measurements of the concentrations of daptomycin.

\section{Measurement of daptomycin concentration}

In each sample, $125 \mu \mathrm{L}$ of plasma and the supernatant obtained from skin tissue was added to $25 \mu \mathrm{L}$ of mefenamic acid (internal standard) dissolved in methanol and $150 \mu \mathrm{L}$ of acetonitrile, vortexed for 40 seconds, and centrifuged for 10 minutes at $11,000 \mathrm{rpm}^{6}{ }^{6}$ The resulting clear supernatants (20 $\mu \mathrm{L}$ ) were injected into high-performance liquid chromatography (HPLC) columns. Total concentrations of daptomycin were determined by the HPLC method of Polillo et al, ${ }^{6}$ with minor modifications. The analytical column was a $\mathrm{C}_{8}$ chromatographic column (BDS Hypersil, 250×4.6 mm, $5 \mu \mathrm{m}$; Agilent Technologies, Tokyo, Japan). The ultraviolet wavelength for daptomycin was $214 \mathrm{~nm}$. The mobile phase consisted of 0.1 M phosphate buffer (pH 2.1):acetonitrile: methanol =52:37:11. The lowest concentration of daptomycin was $0.075 \mu \mathrm{g} / \mathrm{mL}$. The intra- and interday accuracies (as absolute values of the relative errors of the means) and precision (as the coefficient of variation values) were within $10 \%$.

\section{Pharmacokinetic analysis}

A noncompartmental pharmacokinetic analysis was conducted to estimate the rate and extent of daptomycin penetration from the systemic circulation into skin tissue. Maximum concentration $\left(\mathrm{C}_{\max }\right)$ was defined as the observed maximum concentration of daptomycin, and $\mathrm{T}_{\max }$ was the time to $\mathrm{C}_{\max }$. The area under the drug concentration-time curve from 0 to infinity $\left(\mathrm{AUC}_{0-\infty}\right)$ and mean residence time (MRT) were calculated based on the trapezoidal rule. Using plasma-concentration data, total clearance $\left(\mathrm{CL}_{\text {total }}\right)$ was estimated as dose $(50 \mathrm{mg} / \mathrm{kg}) / \mathrm{AUC}_{0-\infty}$, and the volume of distribution at a steady state $\left(\mathrm{V}_{\mathrm{ss}}\right)$ was calculated as $\mathrm{CL}_{\text {total }} \times$ MRT. The elimination half-life $\left(t_{1 / 2}\right)$ was estimated by

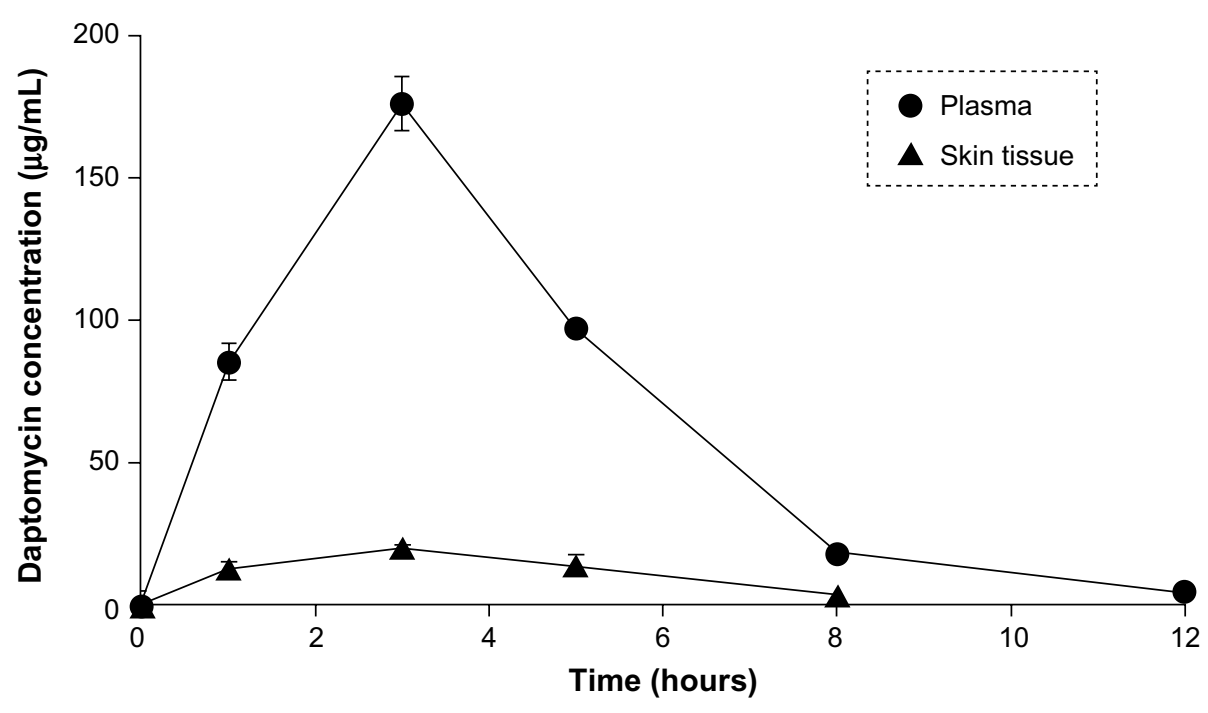

Figure I Observed plasma and skin-tissue concentrations of daptomycin in rats after its single subcutaneous administration (50 mg/kg, $\mathrm{n}=3)$. 
Table I Pharmacokinetic parameters of daptomycin in rats after its single subcutaneous administration $(50 \mathrm{mg} / \mathrm{kg}, \mathrm{n}=3)$

\begin{tabular}{|c|c|c|c|c|c|c|c|c|c|}
\hline \multirow{2}{*}{$\begin{array}{l}\text { Dose } \\
\text { (mg/kg) }\end{array}$} & \multirow{2}{*}{$\begin{array}{l}\mathrm{CL}_{\text {total }} \\
(\mathrm{L} / \mathrm{h} / \mathrm{kg})\end{array}$} & \multirow{2}{*}{$\begin{array}{l}K_{e} \\
\text { (hours }^{-1} \text { ) }\end{array}$} & \multirow{2}{*}{$\begin{array}{l}t_{1 / 2} \\
\text { (hours) }\end{array}$} & \multirow{2}{*}{$\begin{array}{l}V_{\text {ss }} \\
(L / k g)\end{array}$} & \multirow{2}{*}{$\begin{array}{l}\text { MRT } \\
\text { (hours) }\end{array}$} & \multicolumn{2}{|c|}{$C_{\max }(\mu \mathrm{g} / \mathrm{mL})$} & \multicolumn{2}{|c|}{$\operatorname{AUC}_{0-\infty}(\mu \mathrm{g} \times \mathrm{h} / \mathrm{mL})$} \\
\hline & & & & & & Plasma & Skin tissue & Plasma & Skin tissue \\
\hline 50 & $0.06 \pm 0$ & $0.44 \pm 0.06$ & $1.58 \pm 0.23$ & $0.14 \pm 0.02$ & $2.28 \pm 0.33$ & $175.8 \pm 6.3$ & $20.1 \pm 2.2$ & $811.8 \pm 31.9$ & $113.9 \pm 21.8$ \\
\hline
\end{tabular}

Abbreviations: $\mathrm{CL}_{\text {total }}$, total clearance; $\mathrm{K}_{\mathrm{e}}$, elimination-rate constant; $t_{1 / 2}$, elimination half-life; $\mathrm{V}_{\mathrm{ss}}$, steady-state volume distribution; $M R T$, mean residence time; $\mathrm{C}_{\text {max }}$, maximum concentration; $\mathrm{AUC}_{0-\infty}$, area under the plasma concentration-time curve from 0 to infinity.

dividing 0.693 by the elimination-rate constant $\mathrm{K}_{\mathrm{e}}\left(\mathrm{CL}_{\text {total }} / \mathrm{V}_{\mathrm{ss}}\right)$. Since protein binding of daptomycin in rat serum was previously reported to be $89.3 \%,{ }^{7}$ the free $\mathrm{C}_{\max }$ and free $\mathrm{AUC}_{0-\infty}$ for plasma were calculated as follows: $f \mathrm{C}_{\text {max, plasma }}=(1-0.893) \times$ $\mathrm{C}_{\text {max, plasma }}$, and $f \mathrm{AUC}_{0-\infty, \text { plasma }}=(1-0.893) \times \mathrm{AUC}_{0-\infty \text {, plasma }}$.

\section{Results}

The observed concentrations of daptomycin in plasma and skin are shown in Figure 1. Skin-tissue concentrations 12 hours after the administration of daptomycin were not detectable. The following values (mean \pm standard deviation) were obtained: $0.06 \pm 0 \mathrm{~L} / \mathrm{h} / \mathrm{kg}$ for $\mathrm{CL}_{\text {total }}, 0.44 \pm 0.06$ hours $^{-1}$ for $\mathrm{K}_{\mathrm{e}}$, $1.58 \pm 0.23$ hours for $t_{1 / 2}, 0.14 \pm 0.02 \mathrm{~L} / \mathrm{kg}$ for $\mathrm{V}_{\text {ss }}$, and $2.28 \pm 0.33$ hours for MRT (Table 1). $\mathrm{T}_{\max }$ was 3.0 hours for plasma and skin tissue. $\mathrm{C}_{\text {max }}$ and $\mathrm{AUC}_{0-\infty}$ for plasma were $175.8 \pm 6.3 \mu \mathrm{g} / \mathrm{mL}$ and $811.8 \pm 31.9 \mu \mathrm{g} \times \mathrm{h} / \mathrm{mL}$, respectively (Table 1 ). $\mathrm{C}_{\max }$ and $\mathrm{AUC}_{0-\infty}$ for skin tissue were $20.1 \pm 2.2 \mu \mathrm{g} / \mathrm{mL}$ and $113.9 \pm 21.8$ $\mu \mathrm{g} \times \mathrm{h} / \mathrm{mL}$, respectively (Table 1 ). Furthermore, $f \mathrm{C}_{\max }$ and $f \mathrm{AUC}_{0-\infty}$ for plasma were $18.8 \mu \mathrm{g} / \mathrm{mL}$ and $86.9 \mu \mathrm{g} \times \mathrm{h} / \mathrm{mL}$, respectively. The degrees of skin-tissue penetration, defined as the $\mathrm{C}_{\text {max, skin tissue }} / f \mathrm{C}_{\text {max, plasma }}$ ratio and $\mathrm{AUC}_{0-\infty, \text { skin tissue }} / f \mathrm{AUC}_{0-\infty}$ plasma ratio, were 1.0 and 1.3 , respectively.

\section{Discussion}

Previous studies on the rat pharmacokinetics of daptomycin in plasma showed that the $\mathrm{AUC}_{24 \mathrm{~h}}$ of daptomycin was $558 \mu \mathrm{g} \times \mathrm{h} / \mathrm{mL}$ at an intraperitoneal dose of $30 \mathrm{mg} / \mathrm{kg} /$ day, and $605 \mu \mathrm{g} \times \mathrm{h} / \mathrm{mL}$ at a subcutaneous dose of $40 \mathrm{mg} / \mathrm{kg}$ / day, while its $t_{1 / 2}$ was 1.6-2.9 hours. ${ }^{8}$ As shown in Table 1, our results were consistent with these findings. However, the detailed pharmacokinetic parameters of daptomycin were not shown in previous studies, and its penetration into skin tissue was not evaluated. In the present study, we showed that the $\mathrm{C}_{\text {max, skin tissue }} / f \mathrm{C}_{\text {max, plasma }}$ ratio and $\mathrm{AUC}_{0-\infty \text {, skin tissue }} / f \mathrm{AUC}_{0-\infty \text {, plasma }}$ ratio were 1.0 and 1.3, respectively (Table 1 ), and skin-tissue concentrations were equal to free plasma concentrations. Kim et al studied the penetration of daptomycin into soft tissues in healthy subjects with in vivo microdialysis. ${ }^{9}$ They showed that the degree of tissue penetration (defined as the $\mathrm{AUC}_{\text {tissue }}$ ' $f \mathrm{AUC}_{\text {plasma }}$ ratio) was 0.74 , and concluded that intravenous daptomycin penetrated well into the tissues, with a tissue concentration of $74 \%$ of free plasma concentration. They also mentioned that daptomycin protein binding to serum albumin had been shown to be weak (dissociation constant $=90.3 \mu \mathrm{M})$ and reversible, which may contribute to the greater penetration estimated from free drug concentrations in plasma. Our results were consistent with these findings, and thus we consider that skin-tissue concentrations are almost equal to free plasma concentrations after daptomycin injection.

In conclusion, daptomycin exhibited good penetration into skin tissue, supporting its use for the treatment of complicated skin and skin-structure infections. However, further studies are needed in infected patients in order to investigate the relationship between the antimicrobial efficacy of daptomycin and its drug concentrations in skin tissues.

\section{Disclosure}

Seiji Hori has received speaker's honoraria and grant support from Daiichi Sankyo. The other authors report no conflicts of interest in this work.

\section{References}

1. Schriever CA, Fernández C, Rodvold KA, Danziger LH. Daptomycin: a novel cyclic lipopeptide antimicrobial. Am J Health Syst Pharm. 2005;62:1145-1158.

2. Arbeit RD, Maki D, Tally FP, Campanaro E, Eisenstein BI. The safety and efficacy of daptomycin for the treatment of complicated skin and skin-structure infections. Clin Infect Dis. 2004;38:1673-1681.

3. Liu C, Bayer A, Cosgrove SE, et al. Clinical practice guidelines by the Infectious Diseases Society of America for the treatment of methicillinresistant Staphylococcus aureus infections in adults and children. Clin Infect Dis. 2011;52:e18-e55.

4. Jeu L, Fung HB. Daptomycin: a cyclic lipopeptide antimicrobial agent. Clin Ther. 2004;26:1728-1757.

5. Akimoto Y, Nishimura H, Komiya M, Kaneko K, Fujii A, Tamura T. Ampicillin concentrations in human dental granuloma after a single oral administration of talampicillin. Antimicrob Agents Chemother. 1988;32: 566-567.

6. Polillo M, Tascini C, Lastella M, et al. A rapid high-performance liquid chromatography method to measure linezolid and daptomycin concentrations in human plasma. Ther Drug Monit. 2010;32:200-205.

7. Vaudaux P, Francois P, Bisognano C, Li D, Lew DP, Schrenzel J. Comparative efficacy of daptomycin and vancomycin in the therapy of experimental foreign body infection due to Staphylococcus aureus. J Antimicrob Chemother. 2003;52:89-95.

8. Sakoulas G, Eliopoulos GM, Alder J, Eliopoulos CT. Efficacy of daptomycin in experimental endocarditis due to methicillin-resistant Staphylococcus aureus. Antimicrob Agents Chemother. 2003;47: 1714-1718.

9. Kim A, Suecof LA, Sutherland CA, Gao L, Kuti JL, Nicolau DP. In vivo microdialysis study of the penetration of daptomycin into soft tissues in diabetic versus healthy volunteers. Antimicrob Agents Chemother. 2008;52:3941-3946. 


\section{Publish your work in this journal}

Clinical Pharmacology: Advances and Applications is an international, peer-reviewed, open access journal publishing original research, reports,

reviews and commentaries on all areas of drug experience in humans.

The manuscript management system is completely online and includes

a very quick and fair peer-review system, which is all easy to use.

Visit http://www.dovepress.com/testimonials.php to read real quotes from published authors.

Submit your manuscript here: http://www.dovepress.com/clinical-pharmacology-advances-and-applications-journal 